\title{
دوربناي تقدير الذات لدى طفل الروضة في تفاعلاته الاجتماعية
}

\author{
أعراد \\ الباحثة / أمل عوض عبد العال
}

المجلت العلميت لكليت رياض الأطفال ـجامعت المنصورة

المجلد الخامس ـ العدد الأول

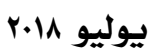




\section{دور بناي تقدير الذات لدى طفل الروضة في

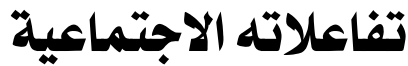

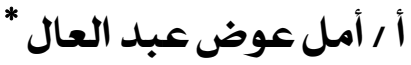

\section{مقدمة}

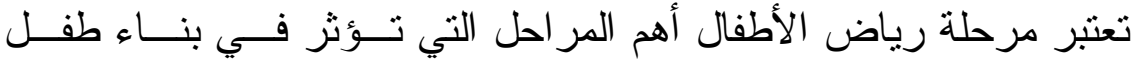

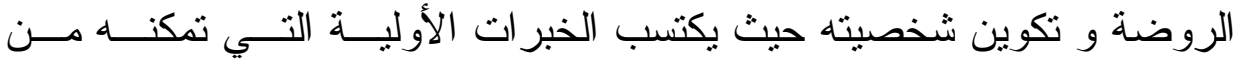
الاعتماد علي نفسه في مر احله العمرية المختلفة وفيها تتنلور أفكاره ومعتقداتسه

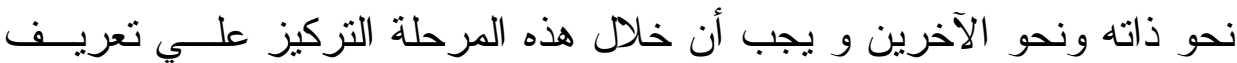

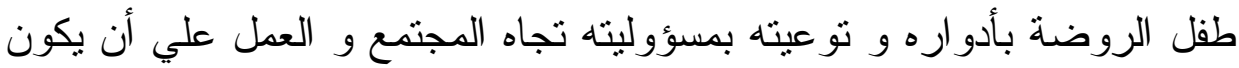

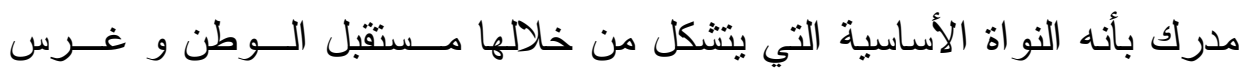

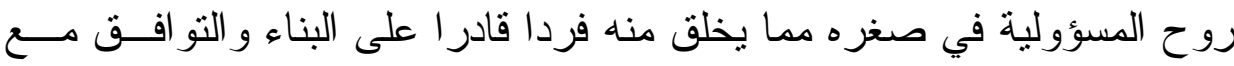
المجنمع

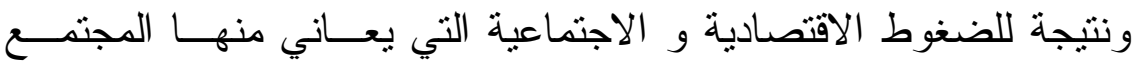

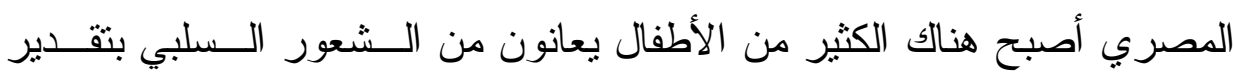
الذات مما ينعكس علي ضعف ثقة الطفل بنفسه وضعف أدائه المدرسي و إصابته بالاكثئاب و القلق و الانطو ائية ومشاكل في النوم . وبتحليل العوامل المؤثرة في ذلك نجد أن الو الدين مـن أهــ العناصـر

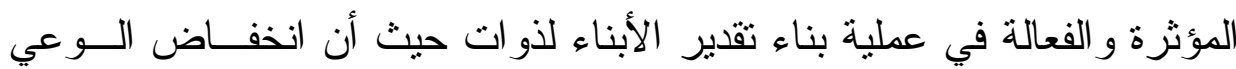
" باحثتّ * 
لدي الو الدين يجعلهم غير قادرين على التعامل مع أبنــائهم ممـــا يــؤدي إلــى انخفاض تقدير الذات لدى الأبناء و ما يترتب عليه من الانسحاب من المـشـاركة الفعالة في الحياة الاجتماعية و حدوث تدهور في مسستوي الــتعلم نــاتج مــن الانخفاض المتز ايد في مستوى التحصيل الدر اسي

(Nanu Elena Doinita, $r \cdot 10$, oV 7 )

ويتناول البحث در اسة مفاهيم تقدير الذات لدى طفل الروضة و استكثاف العو امل المؤثزة على بناء وتتمية تقدير الذات لدى طفل الروضة فــي المجتمــع المصري ومدى انعكاسها على تفاعلاتهم الاجتماعية.

\section{ا 1 ـ مشكلة الدر اسة}

لاحظت الباحثنة من خلال عملها مع أطفــال الروضـــة فـــي المــدارس

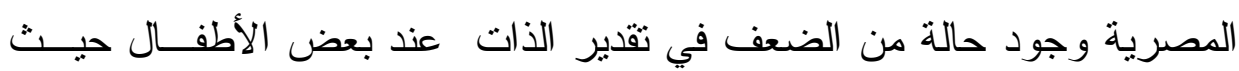
وجدت أن الأطفال ذوى التقدير المنخف للذات يفضلون الابتعاد عن النشاطات الجماعية، ويظهرون الميل إلى الخضوع و التبعية ، حيث بعلق الطفـلـ أهميـــة كبيرة على أحكام الآخرين ، و يعانون من الخجل و الحساسية المفرطة وقلة الثقة بالنفس و يتملكهم استعداد لتوقع الفشل كنتيجة حتمية ،ويفضل العيش في عزلة و وحدة

وترى الباحثة أن هناك لتحديد العو امل المؤثرة في بنـــاء وتقــدير الـــذات

لطفل الروضة ، حيث يمكن استخدامها في تدريب الطفل علي الـسيطرة علـي

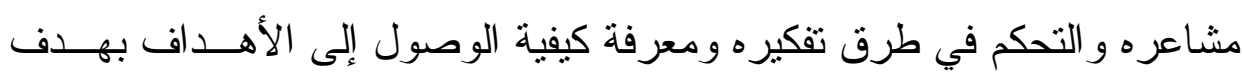
تتمية ضعف تقدير الذات عند طفل الروضة، و هو ما انعكس على بلورة مشكلة الدر اسة و التي تتمنل في التساؤل الرئيسي التالي: 
ما هي العوامل المؤثرة في بناء وتتمية تقدير الذات لدي طفل الروضة

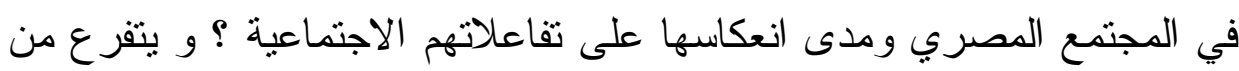

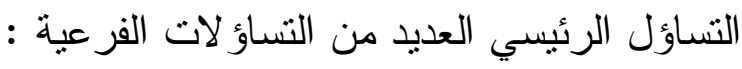

- ما هي العوامل المؤثرة في بناء وتتمية تقدير الذات لدي طفل الروضة

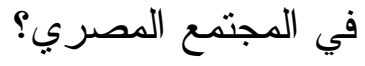
- ما هو اثر بناء وتتمية تقدير الذات لدي طفل الروضة على تتمية نظرة

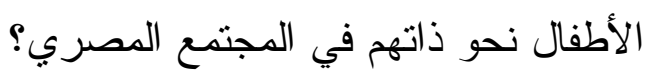

- ما هو اثر بناء وتتمية تقدير الذات لدي طفل الروضة على تتمية نظرة

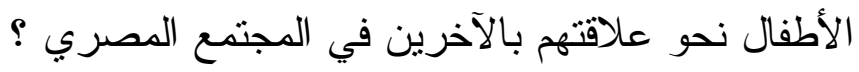
- ما هو اثر بناء وتتمية تقدير الذات لاي طفل الروضة على تتمية سلوك

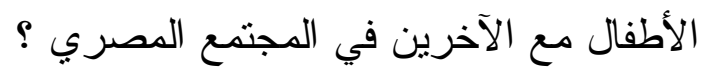

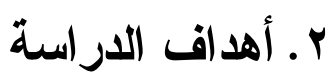

- - الكثف عن أهم العو امل التي تساعد في توجيه الأداء لتتمية تقدير الذات عند بعض أطفال الروضة ذوب تقدير الذات المنخفض. -

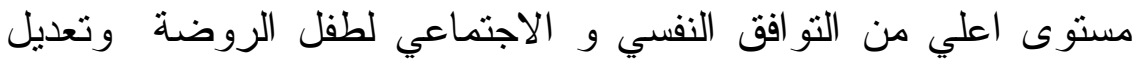
سلوكياته للتخلص من المشاعر السلبية حول ذاته - محاولة التوصل إلى تصور مقترح بسعى إلى توضـيـح آليـات تطبيــق

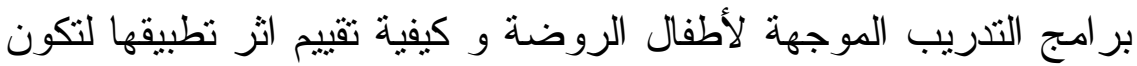

$$
\text { إطار يسترشد به العاملين في هذا المجال }
$$




$$
\begin{aligned}
& \text { r. أهمية الدراسة } \\
& \text { تكمن أهمية البحث الحالي فيما يلي: } \\
& \text { الأهمية النظرية: }
\end{aligned}
$$

- - تحديد المفاهيم السلبية لتقدير الذات لتضمينها فى الدر اسة و ايجــاد حلـــول

لذلك.

- - إلقاء مزيد من الضوء على طبيعة مشكلة تقدير الذات وكيفية مو اجهتهــا

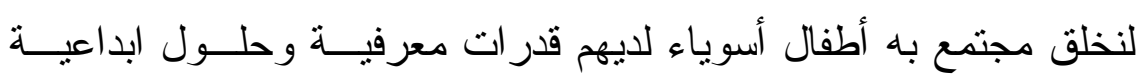

$$
\text { للمشكلات. }
$$

- توجيه أنظار المهتمين بمرحلة رياض الأطفال لتوظيف العو امل المــؤثزة في بناء وتتمية تقدير الذات لدى طفل الروضة في حل المــشكلات التـي

$$
\text { تو اجهرم مع هؤ لاء الأطفال. }
$$

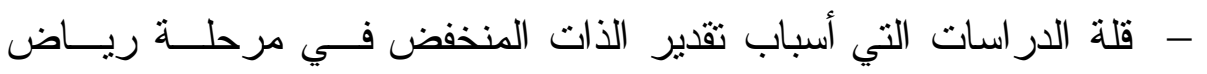
الأطفال لتكون تلك الدر اسة نواة لإلقاء الضوء على دور تلأك العو امل في

$$
\text { إحداث التغير وحل المشكلات التي تو اجنا مع الأطفال. }
$$

الأهمية التطبيقية:

- - تدريب الأطفال على تقدير الذات لتحقيق التو افق النفـسي فــي المجتمــع وتحقيق الكفاءة الثخصية و الثقة بالنفس لدى الطفل

- يمكن لهذه الدر اسة أن تقدم رؤية علمية وتطبيقية في مجال تتمية وتدريب الطفل على التصرف بطريقة واقعية في المو اقف الاجتماعية. 
- قد يؤدى تتمية نقدير الذات لدي عينة الدراسة إلى التغلب علي الصعوبات

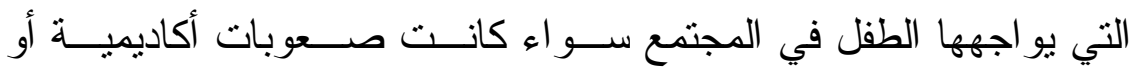

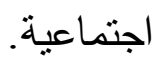

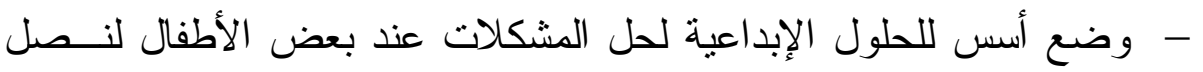

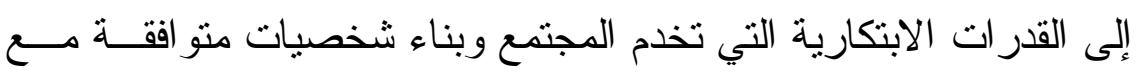

$$
\text { بعضها البعض. }
$$

- تقديم الإرشاد الأسرى المناسب ليعرف الو الدين مشاكل الأبنــاء وتقـــيم

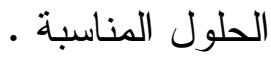

\section{؛ مصطلحات الار اسة}

\section{- تقدير الات Self esteem}

يعرف (محمد عاطف غيث، 2006) تقدير الذات على انه تقيــيم يــضعه

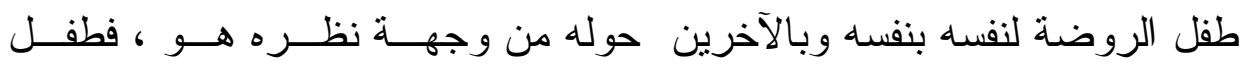

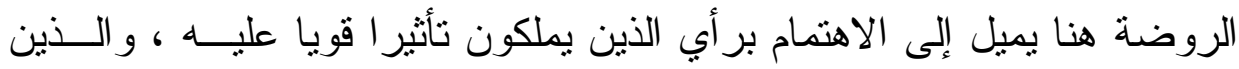

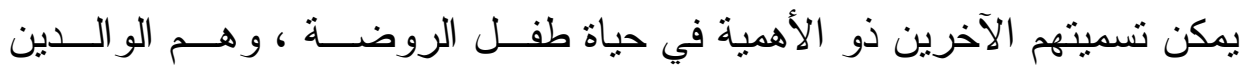

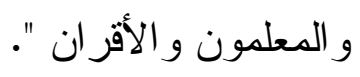

ويعرف " مايكل فورتين " قيم تقدير الذات بأنها القيم الني تـسنلزم مسن

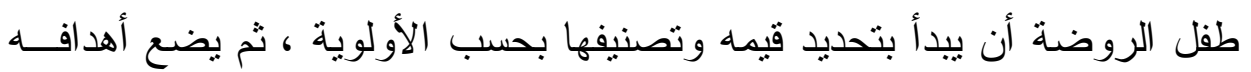

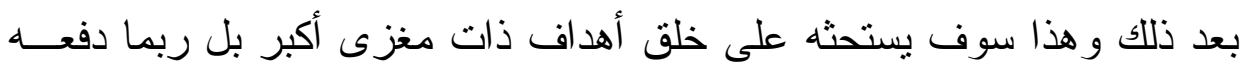

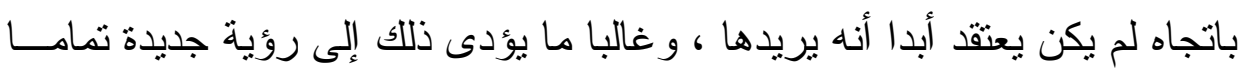

( مايكل فورتين ، 2009 ، 116 ) 
وتعرفه (إيمان أبو الحمد، 2016) بأنـه إحساس طفـلـ الروضـــة بقيمتــهـ

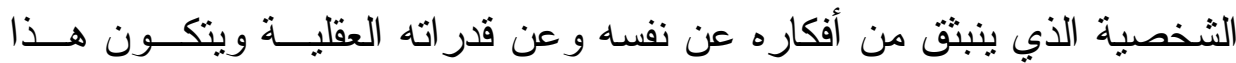
في إطار حاجات الطفولة وخاصـة الحاجة إلـى الاســتقلال و الحريــة و القبـــل و النجاح

- التعريف الإجرائي لتقدير الذات

تعرف الباحثة قيم تقدير الذات إجر ائيا بأنها قدرة الطفل علــى أن يحــدد

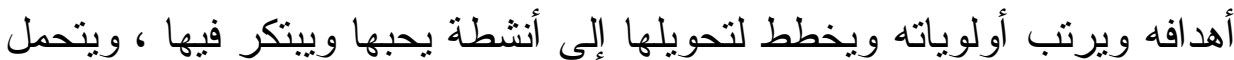
مسئوليتها بما يتفق مع قدر اته الخاصة ، وبهذا يصبح قادر ا على التقاعـلـ مــع الآخرين ومع المو اقف الخارجية مما يجعله فرد مختلف يتمتع بالأمان و الـسعادة ويتحدد بالدرجة التي يحصل عليها الطفل في المقياس.

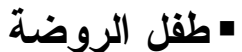

الطفل الذي يلتحق برياض الأطفال التابعة لوزارة التربية و التعلــيم مدــن

$$
\begin{aligned}
& \text { تتر اوح أعمار هم من ه إلى } 7 \text { سنوات . } \\
& \text { ه. الدر اسات السابقة } \\
& \text { دراسة (طاهر محمد ، 2018) }
\end{aligned}
$$

بعنوان تحسيـن الكفاءة اللغوية وتقدير الذات لدى الأطفال ذوي صعوبات

القر اعة باستخدام بعض فنيات البرمجة اللغوية العصبية هدفت الدر اسة إلى الكثف عن فعالية برنامج تدريبي في تحسيــن الكفاءة اللغوية وتقدير الذات لدى الأطفال ذوي صعوبات القر اءة باستخدام بعض فنبــات البرمجة اللغوية العصبية البية 
وتضمنت الدر اسة (40) تلميذاً جمعيهم من مدرســتي (أثـــمون للتعلــيم

$$
\text { "الأساسي - السلام الابتدائية)" }
$$

توصلت النتائج إلى فعالية برنامج تـريبي في تحسيـن الكفــاءة اللغويـــة وتقدير الذات لدى الأطفال ذوي صعوبات القر اءة باستخدام بعض فنيات البرمجة اللغوية العصبية ، و استمر ار فعالية برنامج تدريبي في تحسيــن الكفاءة اللغويـــة وتقدير الذات لدى الأطفال ذوي صعوبات القر اعة باستخدام بعض فنيات البرمجة اللغوية العصبية.

$$
\text { دراسة (هالة عبد الرحيم، 2017) }
$$

بعنو ان الذكاء الوجداني و علاقته بتقدير الذات وجودة الحياة لدي عينة من

$$
\text { طلاب الجامعة }
$$

هدفت الدر اسة إلي اختبار العلاقة بين الذكاء الوجداني و كل مــن تقــير

$$
\text { الذات وجودة الحياة لدى عينة من طلاب الجامعة }
$$

تكونت عينة الدر اسة من (300) طالباً وطالبــةً مــن طــلاب الجامعــة،

$$
\text { مقسمين إلى (150 طالباً، } 150 \text { طالبةً) }
$$

و توصلت الدر اسة إلي وجود علاقة إحصائية دالة بين الذكاء الوجــداني وكل من تقدير الذات وجودة الحياة لدى عينة من طلاب الجامعة

$$
\text { در اسة (سلمى سالم، 2017) }
$$

بعنو ان صورة الذات وصورة الأسرة لدى الأطفال المكتئبين 
هدفت الدراسة إلي التعرف على ملامح صورة الـــات لــــى الأطفــال

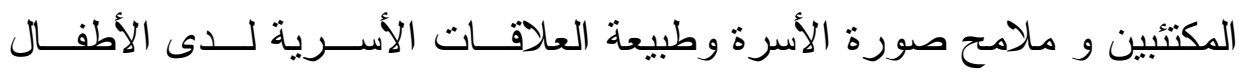
• المكتئين

تكونت العينة من 8 أطفال (4 من الـــكور و4 مــن الإتــات) تــــراوح

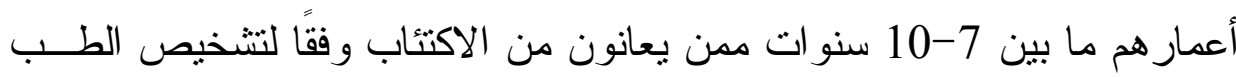
نفسي من قبل الطبيب النفسي المختص.

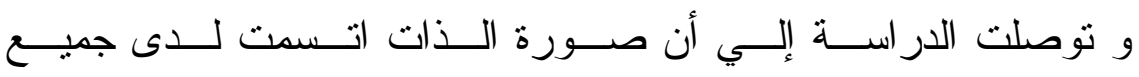

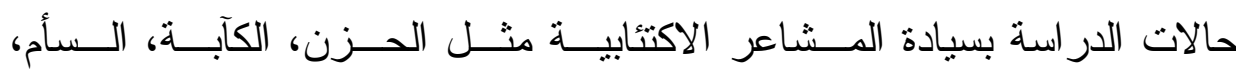

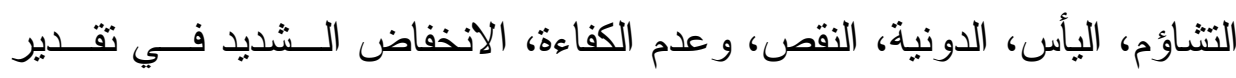
الذات.

دراسة (Rebecca L. Forrestera, Y P V ) بعنو ان تقدير الذات و إصابة عدم الانتحار في مرحلة البلوغ هدفت الدراسة إلي فحص العلاقة بين تقدير الذات و إصابة عدم الانتحار في مرحلة البلوغ اثتملت الدراسة علي عينة مكونة من (300) ممن في مرحلة البلوغ و توصلت الدر اسة إلي تحديد سبعة عشر دراسة و أثنارت إلـى وجــود

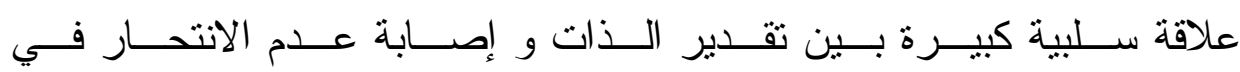

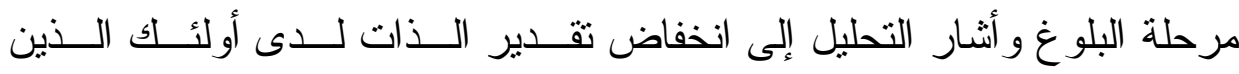
لديهم تجارب من إصابة عدم الانتحار في مرحلة البلوغ مقابل أولئك الذين ليس التيل لايهم ليهم 


\section{دراسة (صالحة العجمي، 2017)}

بعنو ان أساليب مو اجهة ضغوط الحياة وعلاقتها بكل من تقــير الـــات، و الجمود لدى العاملين في وز ارة الداخلية بسلطنة عُمان

هدفت الدراسة إلي التعرف على العلاقة بين أساليب مو اجهــة ضــنوط الحياة وكل من تقدير الذات و الجمود الفكري لدى العاملين فـــي وزارة الداخليـــة

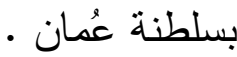

تكونت عينة الدراسة الميدانية من (150) من العاملين بــوزارة الداخليــة

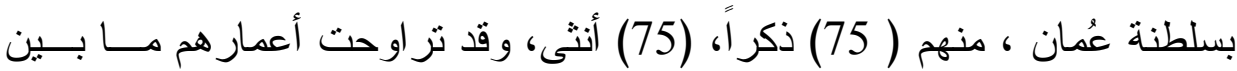
(30-50 سنة)، بمتوسط عمري قدره (37.5 سنة)

توصلت الدراسة إلي توجد علاقة إحصائية دالة أساليب مو اجهة ضــغوط الحياة وكل من تقدير الذات و الجمود الفكري لدى العاملين فـــي وزارة الداخليــة بسلطنة عُمَان دراسة (سعاد الجوهري، 2017) بعنوان المهارات الاجتماعية وعلاقتها بأساليب مواجهة الضغوط النفسية وفعالية الذات لاى عينة من طلاب الجامعة بليبيا هدفت الدراسة إلي التعرف على العلاقـــة بــين المهــار ات الاجتماعيــة

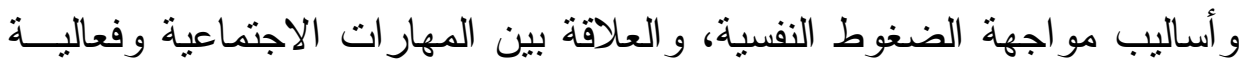
الذات لدى عينة من طلاب الجامعة بليييا 


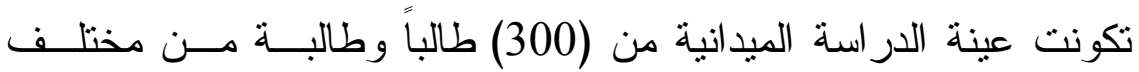

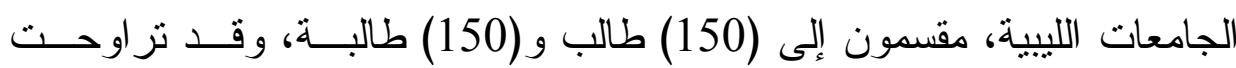

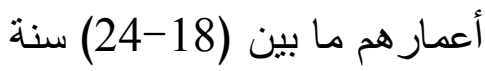

توصلت الدراسة إلي وجود علاقــة إحـصـائية دالــة بــين المهــارات الاجتماعية وأساليب مواجهة الضغوط النفسية كما توجد علاقة إحصائية دالة بين المهار ات الاجتماعية وفعالية الذات لدى عينة من طلاب الجامعة بليييا 7. متغير ات وفروض الار اسة تتكون متغير ات الدراسة من المتغيرات التالية المتغير المستقل: تتمية تقدير الذات

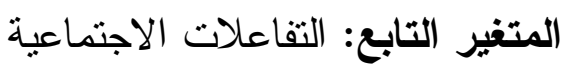

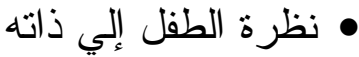
• • نظرة الطفل إلي علاقته بالآخرين

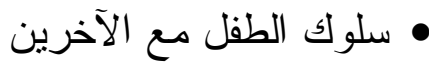
وسوف يتم اختبار الفروض التالية

- توجد فروق ذات دلالة إحصائية بين منوسطات درجـات نظــــة أطفــال الروضة لأنفسهم في المجمو عتين التجريبية و الضـابطة بعد تتميــة تقــدير

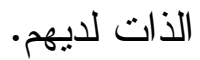
- توجد فروق ذات دلالة إحصائية بين متوسطات درجــات نظـــرة أطفــال الروضة علاقته بالآخرين في المجموعتين التجريبية و الضابطة بعد تتمية تقدير الذات لديهم. 
- توجد فروق ذات دلالة إحصائية بين منوسطات درجات ســلوك أطفــال

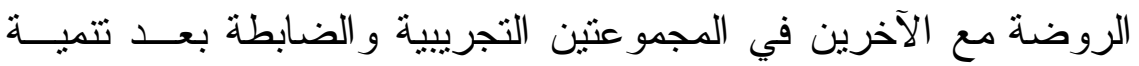

$$
\text { V. حدود الدراسة الذات لديهم. }
$$

$$
\text { يمكن بيان حدود البحث كالتالي: }
$$

\section{- حدود موضوعية}

تشمل الحدود الموضو عية استكثناف العو امل المؤثرة على بنــاء تقــدير الذات لدى طفل الروضة ومدى انعكاسها على تفاعلاتهم الاجتماعية. • حدود بشرية

تشمل الحدود البشرية أطفال الروضة مدــن يلتزمـــون بالحــضور إلـىى الروضة و تكون نسبة ذكائهم متوسطة و ألا يكونو ا ممن يعاني من إعاقة صحية

$$
\text { مؤثزة على الأداء. }
$$

يقتصر جمع و تحليل البيانات تقدير الذات أطفال الروضة خلال الفتـرة

$$
\text { • من يناير } 2019 \text { نتتهي في يونيه } 2019 \text {. }
$$

تتمنتل في مدرسة فخر الدقهلية للغات الرسمية التابعـــة لمديريــة التربيـــة

و التعليم بمحافظة الدقهلية.

$$
\text { 1. مجتمع و عينة الار اسة }
$$

يتضمن مجتمع البحث أطفال الروضة ممن يتــراوح أعمـــار هم مــابين (5-6) سنوات و تــضمنت عينــة الدر اســـة الأساســية اختيــار عـدد مــن

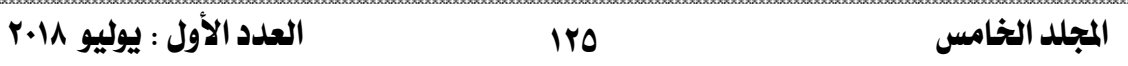


مفردات مجتمع الدر اسة مكونة من 30 طفل (15 طفل للمجموعة الـضـابطة -

15 طفل للمجموعة التجريبية) بطريقة عشو ائية مــن مدرســة فخــر الدقهليــة

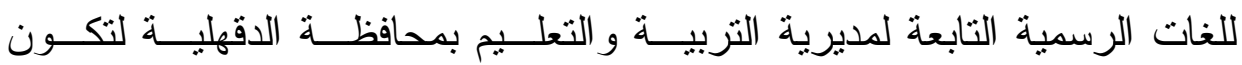
العينة ممثلـه

9 ـ أسساليب المعالجة الإحصائية

يتم الاعتماد علي عدد من الأساليب لتحليـلـل البيانــات و التــي يمكـن



أسلوب التحلبل الانتقادى عن طربق :

- المر اجعة التحليلية الانتقادية للبحوث و الدر اسات في هذا المجال . - الدر اسة التحليلية للبيانات المختلفة و ما يمكن استتباطه من حقائق و نتائج توضحها دلالات تلك البيانات . هالأسالبب الإحصائبة بو اسطة البر امج الإحصائبة

سوف يلجأ الباحث إلي استخدام بر امج الحزمـــة الإحــصائية (SPSS) لإيجاد العلاقات بين المتغير المستقل و المتغير ات التابعة و سوف يعتمد الباحث علي الأساليب الإحصائية التالية : - - أسلوب التوزيع التكر اري و النسبي - 


$$
\begin{aligned}
& \text {. } 1 \text { ـ أدو اث الدر اسةة } \\
& \text { استخدمت الباحثة الأدوات التالية: } \\
& \text { 1- مقياس ستانفورد بينيه الصورة الخامسسة ( مر اجعــة و إثـــر اف د ) }
\end{aligned}
$$

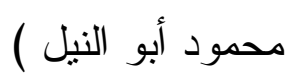

$$
\begin{aligned}
& \text { r- قائمة تقدير الذات للأطفال (إعداد /د عبداللطيف محمد /V . . r ) } \\
& \text { 1 إل إطار النظري } \\
& \text { 1/11 }
\end{aligned}
$$

هنالك العديد من التعاريف التي تتاولت مفهوم تقدير الذات حيــث بـشـير

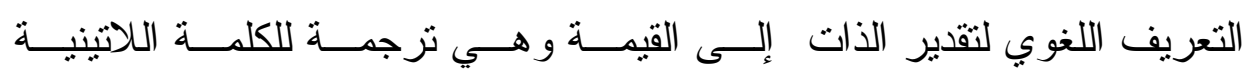
aestimare وتعني إعطاء قيمة لشيء ما ثم اشتق منها كلمة esteem التي تعني تقدير، ثـــ صارت مصطلحا مركبا self-esteem وتعني تقدير الذات، و يثنير المــصطلح إلي أن يعطي الثخص لنفسه قيمة ذاتية إيجابية تتعكس علي مدى قبوله لذاتـهـه و

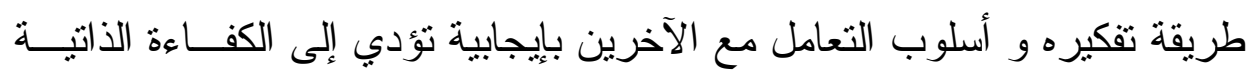
في علاقة الطفل بنفسه و بالآخرين. بينما يثير تعريف كوبر سميث Cooper Smith لتقدير الذات بأنه حكـم للطفل على قيمته الذاتية و التي يتم التعبير عنها من خلال اتجاهاته نحو نفـسه و تعتمد الصورة الذاتية للطفل عن نفسه على تقديره لذاته 


$$
\text { و يشير تعريف كوبر سميث إلى ثلاثة جو انب : }
$$

- التعريف يركز على تقدير الذات في المو اقف العامة الثابتـــة أكثتـر مــن المو اقف الطارئة و تعالج المو اقف الثابتة أو الطارئة مستوى تقدير الطفل لذاته و لكن الاختلاف يكمن في عمومية المفهوم وثباته، و الظروف التـي يتكون خلالها. - تقدير الذات يختلف بناء على الخبر ات و النوع و العمر وبعض الظــروف الأخرى - تقييم الذات يختص بعملية الحكم Judgment و اختبار الطفــل لأدائـــه

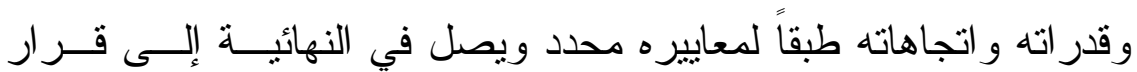

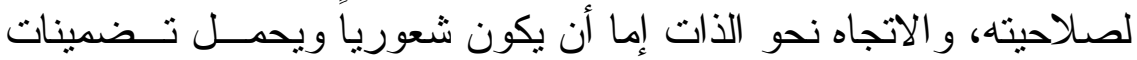
سالبة أو موجبة تتضافر مع العملية العقلية والدافعية وهكا حاجات الطفل لا يمكن عزلها عن اتجاهاته نحو ذاته.

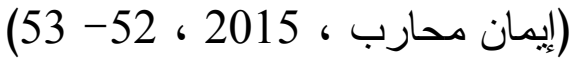

1/ العو امل المؤثرة في تقدير الذات

تقدير الطفل لذاته يتأثز بقدر اته و استعداداته الجسمية حيــث أن صــورة الجسم و المظهر الخارجي و القدر ات العقلية لهم دور هام في تقييم الطفـلـل لذاتــــ وبقدر خلوه من العيوب أو القصور في ملامحه الجسدية فانه يتخلص من القلـق أو عدم الاستقرار النفسي، وقد أثنار أدلر إلى أن القصور العــضوي اي وجــود خلل جسمي في أي عضو يؤثز على صحة الشخص النفسية وبشعوره بــالعجز

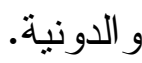
(سيتو مولياديا، و اهيو ر اهاردجو ا، هيرو باسوكيا، 2016 : 608-603) 
إن إحساس الإنسان بذاته وتصوره عنها هو قبل كل شيء تصور لجسمه،

فالطفل يميز ذاته عن ذوات الآخرين عن طريقة إحسـساسه الخــاص بنـشاطه العضلي وطوله ووزنه ولون شعره ومدى تحقيقه لمتطلبات النمو فــي الوقــت المناسب.

وتلعب القدرة العقلية دورًا هامًا في التأثثر على تقدير الذات ففي المدرسة

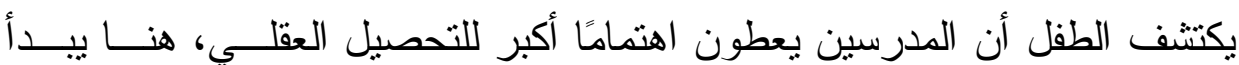
الطفل في النظر إلى نفسه هل هو بطئ أم متوسط، أم سريع التعلم، وذلك حتـى يقيم أداءه العقلي و الدر اسي، ووع تقدم السن يبدأ في تقييم قدر اته الطائفية أيــضًا مع القدرة اللغوية أو الفنية أو الميكانيكية وبذلك يستطيع الطفل أن يفهم قدراتــه الحقيقة، ويكون صورة عن ذاته يرضى عنها أو يرفضها. (أيسم سيدا أونينا، فاطمة ميرفي أولوسويا، 2015، 1163- 1168)

توجد العديد من المؤثز ات الاجتماعية التي تغير من تقدير الطفل لذاتــه منل الأصدقاء و الأسرة و الواديين و المدرسة حيث تتغير صورة الـذات مسـن خلال التفاعل الاجتماعي و في إطلار البناء الاجتماعي الذي يعيش فيه الطفـلـل و

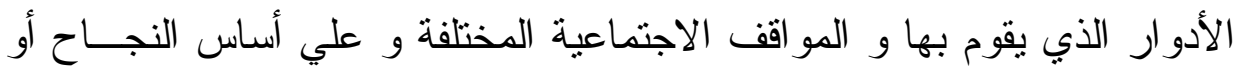
الفشل في التفاعل الاجتماعي يتم رسم الصورة الذاتية للطفل أي انه يوجد هناك نوعان من العو امل المؤدية إلــى تنـــوين تقـدير ذات مرتفع أو منخفض وهما: - عو امل تتعلق بالطفل نفسه: فلقد ثبت أن درجة تقدير الذات لدي الطفل تتحدد بقدر خلوه من القلق أو عدم الاستقر ار النفسي، بمعنى أنـــهـ إذا كـــان الطفــلـ

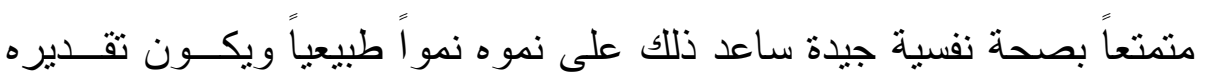


لذاته مرتفعاً، أما إذا كان الطفل من النوع القلق غير المستقر فإن فكرته عــن ذاته تكون منخفضة وبالتالي ينخفض تقديره لذاته.

(عصام ثنابت ، 65 610،

- عو امل تتعلق بالبيئة الخارجية: و هي متصلة بظروف التتـشئة الاجتماعيــة و الظروف التي تربي ونشأ فيها الطفل وكذللك نوع التربية ومنها: هل يسمح له بالمشاركة في أمور العائلة.

$$
\text { • هل يقرر ما يريد. }
$$

ها نوع العقاب الذي يفرض عليه؟

$$
\text { • نظرة الأسرة لأصدقاء الطفل (محبة أم عداوة). }
$$

و بقدر ما تكون الإجابة على هذه الأسئلة موضو عية وإيجابية بقـدر مـــا تؤدي إلى درجة عالية من ثقدير الذات ومن هذه العو امل.

(عصام ثابت ، 2010، 64 - 65 (ع5)

1/ النظريات المفسرة لتقدير الذات

تتاولت العديد من النظريات مفهوم تقدير الذات حيــث تضمنت نظريــة فستنجر Festinger 1909 أفكار حول الذات بأن الأفكار و المـشـاعر المرتبطة

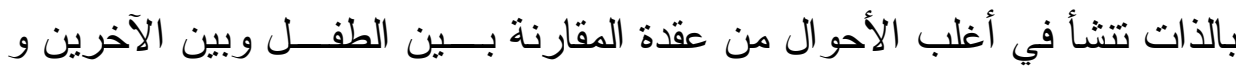
تعتمد نظريته علي عمليات المقارنة الاجتماعية ويختلف تقدير الطفل لذاته فـي المو اقف المختلفة تبعا لتغير مفهومه عن ذاته من خــلال علاقاتــه الثخــصية بالآخرين و الطفل بقدر ذاته من خلال مقارنة نفسه بالمحيطين به و في حالـــة أن 
تكون العلاقة إيجابية يقدر الطفل ذاته بدرجة عالية ويقدر ذاته بشكل سـالب إذا

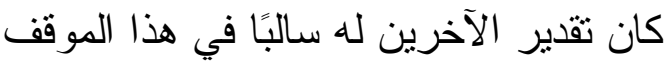

(جيف ستون ، 2000، 1- 15)

و تعتبر نظرية روزنبرج 1965 من من أو ائل النظريات التـي

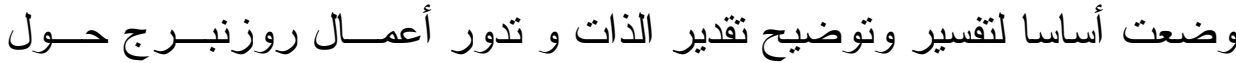

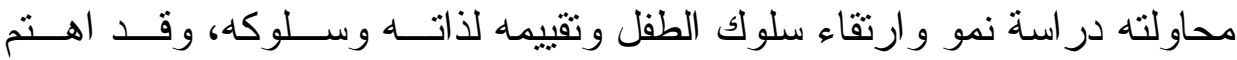

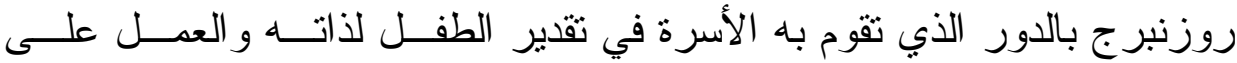

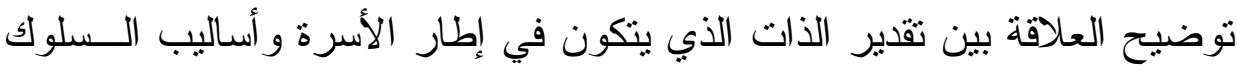
الاجتماعي اللاحق للطفل فيما بعد حيث ظهرت هذه النظرية من خلال در اســته

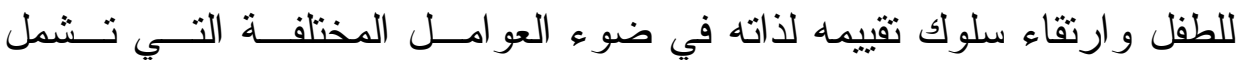

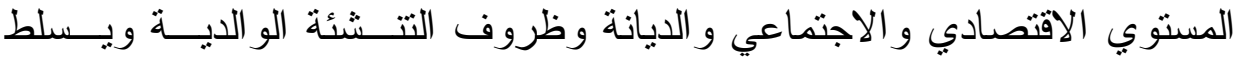

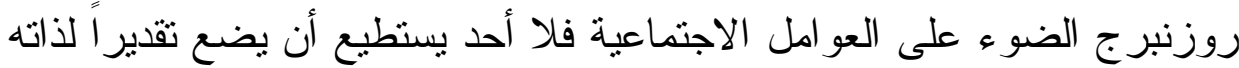
و الإحساس بقيمتها إلا من خلال الآخرين و اهتم بالتغيرات التي تحدث في تقدير

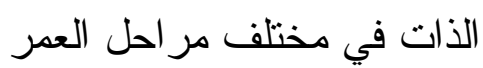

(إيناس البلتاجي ، 2014 ، 12-13)

ويرى بندر" سو 199 Bender " أن روزنبــرج وضــع للــذات ثلاثــة تصنيفات هي الذات الحالية أو الموجودة و تثتير إلي كيفية رؤية الطفـلـ ذاتـهـ

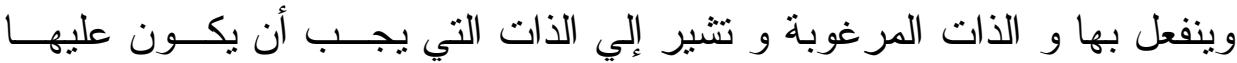
الطفل و الذات المقدمة و تثتير إلى صور الذات التي يحاول الطفل أن يوضــــها

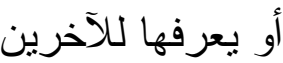
(تافرودي، سوان، 2001، 653 - 673) 
وتصف نظريــة زيلـر 1969 تقدير الـــات بأنه تقدير يقوم به

الطفل لذاتها ويلعب دور المتغير الــوسيط وعلى ذلـــك فعندما تحدث تغيرات في بيئة الثخص الاجتماعية فإن تقدير الذات هو العامل الذي يحدد نوعية التغيرات

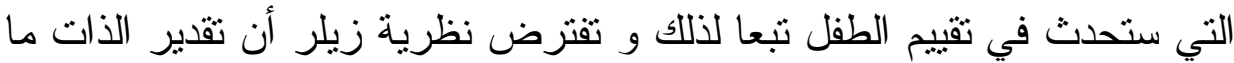

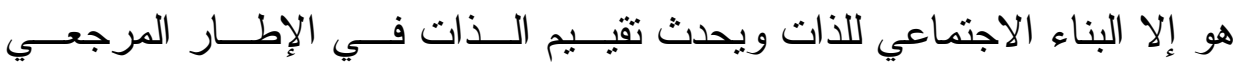
الاجتماعي للمحيط الذي يعيش فيه الطفل

(ضيف العطوي ،2006 ، 18-19 )

و أنثارت نظرية كوبر سميث 1976 Cooper Smith إلى أن جـذور تقدير الذات تكمن في عاملين رئيسين الأول يتعلــق بمـــى الاهتمــام و القبـــول

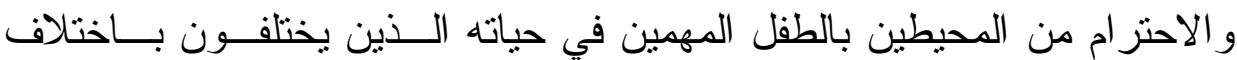

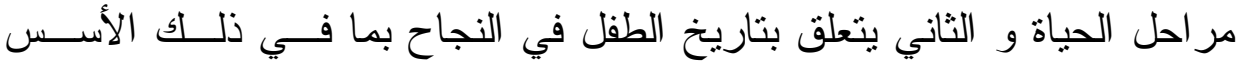

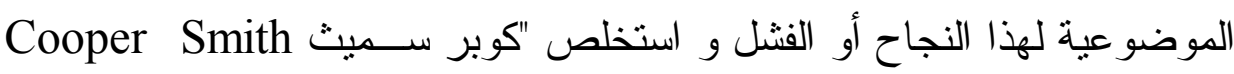

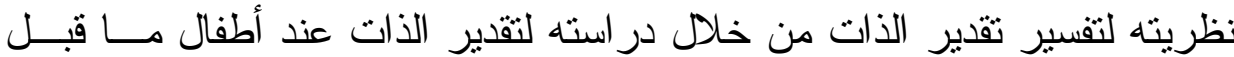

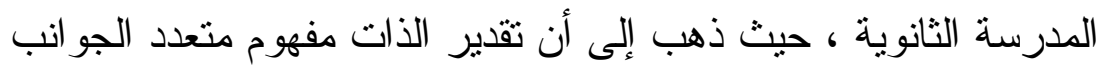

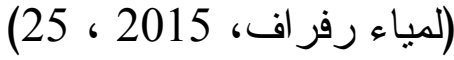

و اهتمت نظرية إبشتاين Epstion إلى نوضيح ماهية مفهوم الذات بقوله

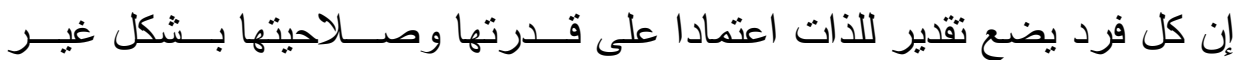
مقصود طبقا لخبر اته المختلفة ويشكل الجزء الأكبر من هذه الصياغة احتر امسـا كاملا للات بمقار الخبرات المرتبطة بالإنجاز وبزيادة تقدم الطفل فإن نظريته

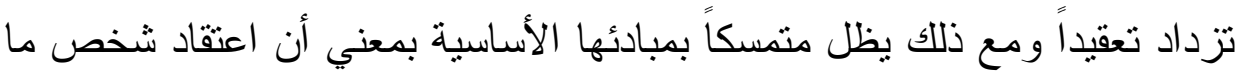

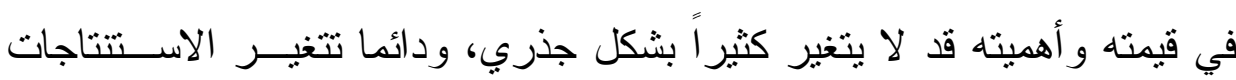

r.11 العدد الأول : يوليو

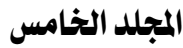


المستخلصة من هذه الاعتقادات أو يعاد فحصها و التحقق منها مرة أخرى بتقــدم

$$
\text { العمر وزيادة خبر ات الحياة. }
$$

(رجاء أبو شمالة ، 2016، 52) (ر)

تقوم نظرية روجرز على النظرة لطبيعة الإنسان تلك النظرة التي تقترض وجود قوة دافعة لاى الإنسان وهي النزعة إلى تحقيق الذات حيث جعلـت مــن

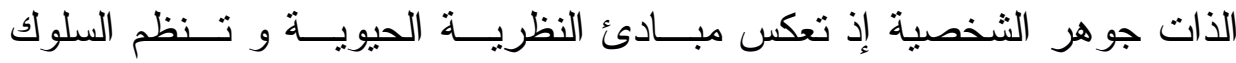

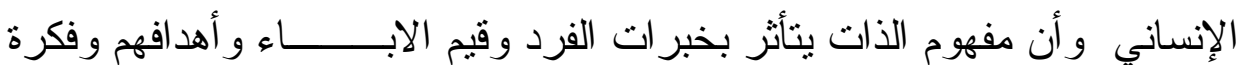

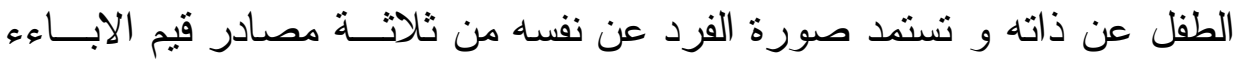

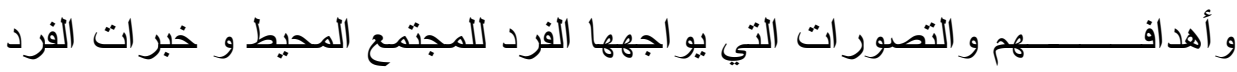
المباشرة و التصور ات التي تكون الصورة المثالية التي يرغب أن يكون عليها

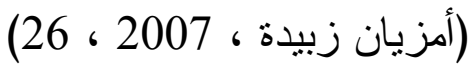

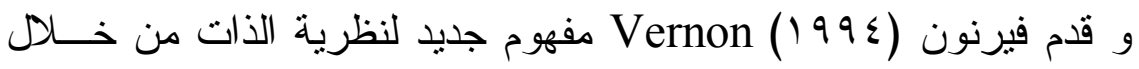

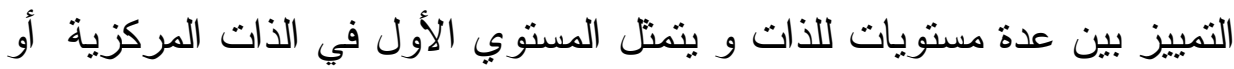

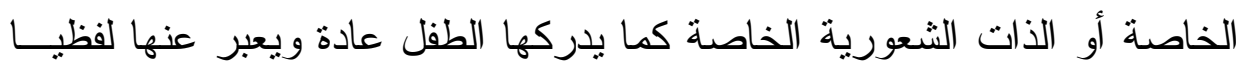

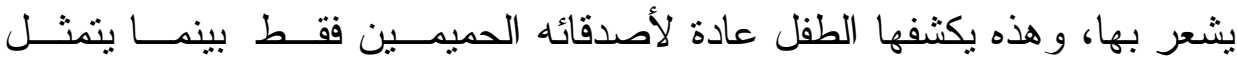

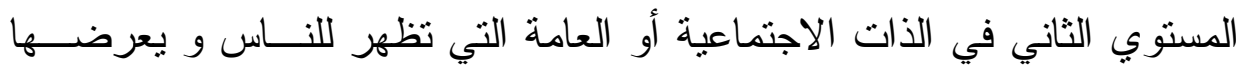

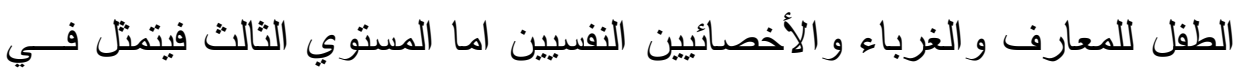

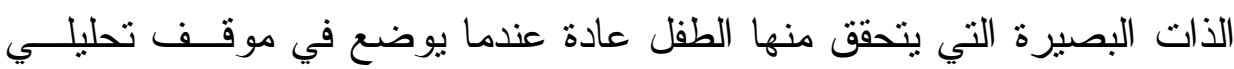

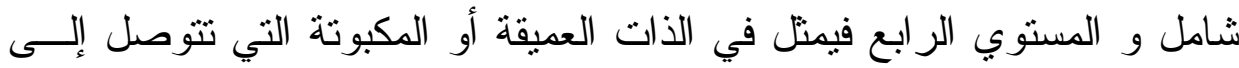
صورتها عن طريق التحليل النفسي. (سلوى علي ، 2011، 36-37) - (س) 
11 - أنواع تقدير الذات

يري leord \& andre أن هنالك ثلاثة مصادر أساسية تؤثر في تقـدير

$$
\begin{aligned}
& \text { الذات لي الأطفال و المر اهقين } \\
& \text { مالبيت و الو الدين } \\
& \text { • المدرسة و المدرسون } \\
& \text { الأقران و الأصدقاء و الدقربون }
\end{aligned}
$$

كما يعتبر المظهر الخارجي و النجاح المدرسي و المهارات و العلاقــات

الاجتماعية و القبول من المحيط من أهم العو امل المؤثرة في تكوين تقـدير ذات ايجابي أو سلبي

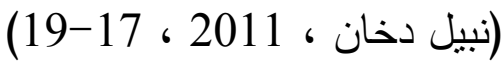

يمكن تقسيم تقدير الذات إلى تقدير الذات العالي ( الايجــابي ) و تقـــير

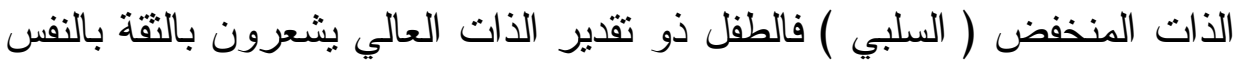

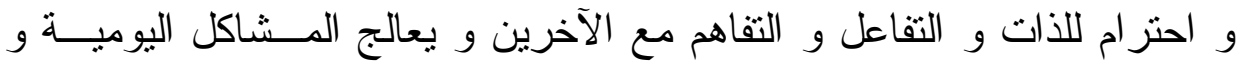

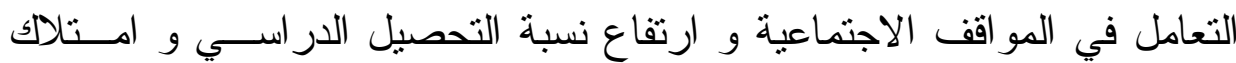

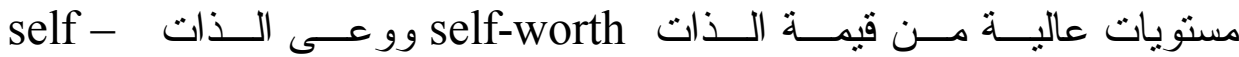
awareness ومشاعر الرضاو مشاعر السيطرة على الحياة .

(انتصار منصور ، 2012 ، 78-79)

و تعرف نظرية التعلىــــالاجتماعي مفهوم الذات الموجبة بأنها ميل لــدى

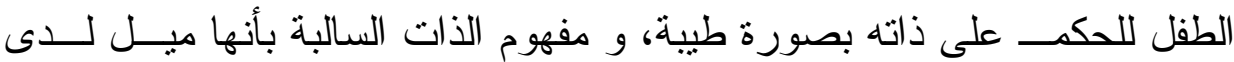
الطفل لنقد ذاته و التقليل من شأنه وقيمتها

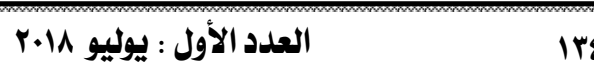

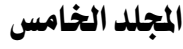


بينما يعرف روزنبرج تقدير الذات علي انه اتجاهات الطفـلـل الـشـاملة

سالبة كانت أو موجبة نحو نفسه وهذا يعني أن تقدير الذات المرتفــع معنـــاه أن

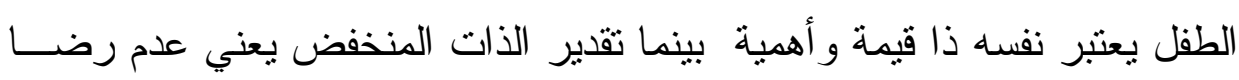
الطفل عن نفسه أو رفضه لذاته.

و هناك ثلاثة أنو اع لتقدير الذات بناء علي نظرية التكوين كالتالي:

- تقدير الذات المستمر : يتمنل في معرفة الثخص كل شيء عن نفسه. - تقدير الذات الموقفي: يتمثل في المشاعر التي يدركها الطفل عن نفسه فـي مئي موقف معين. -تقدير الذات المجتمعي: بيتمثل في شعور الطفل عن نفسه النابع من تـأثير المجتمع.

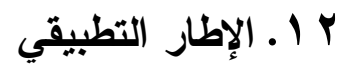

r 1/1 الاختبار الإحصائي للقرض الأول

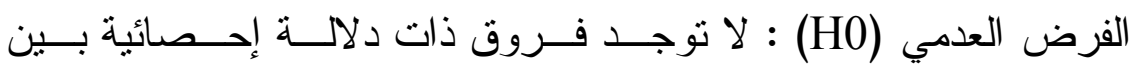

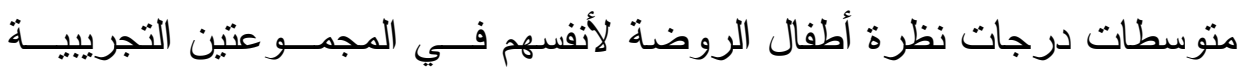
و الضابطة بعد تتمية تقدير الذات لديهم. الفرض البديل (H1) : : توجد فروق ذات دلالة إحصائية بين متوســطات

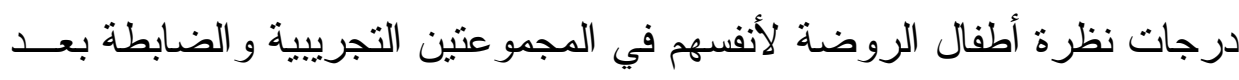
تتمية تقدير الذات لديهم. 


\begin{tabular}{|c|c|c|c|}
\hline \multicolumn{4}{|c|}{ جدول رقم (1) يوضح نتائج اختبار Mann-Whitney } \\
\hline \multirow{2}{*}{ الاحتمال(Sig) } & \multirow{2}{*}{ إحصائي الاختبار } & \multicolumn{2}{|c|}{ متوسط الرتب } \\
\hline & & المجموعة الضابطة & المجموعة التجريبية \\
\hline 0.041 & 19.26 & 206.22 & 234.64 \\
\hline
\end{tabular}

مالتعليق على النتائج :

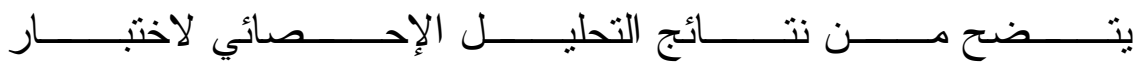

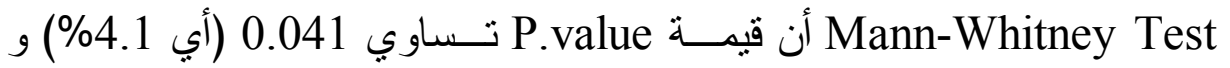
هي اقل من مستوي المعنوية 5\% و بالتالي فإنتا نرفض الفرض العدمى و نقبــلـ

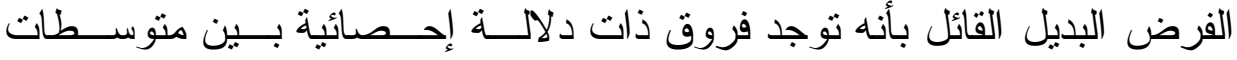

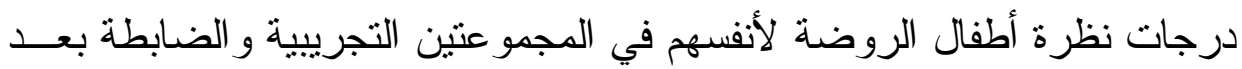
تتمية تقدير الذات لديهم.

\section{r r T الاختبار الإحصائي للفرض الثاني}

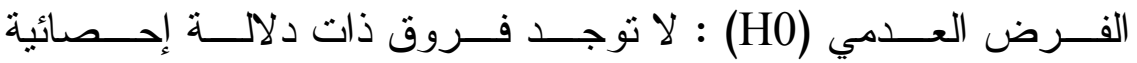

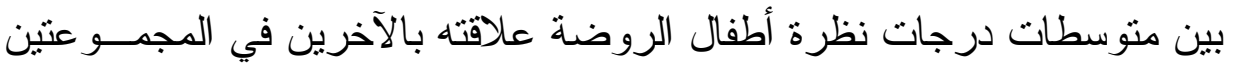
التجريبية و الضابطة بعد تتمية تقدير الذات لديهم.

الفرض البديل (H1) : نوجد فروق ذات دلالة إحصائية بين متوســات

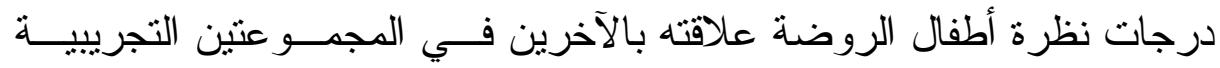
و الضابطة بعد تتمية تقدير الذات لايهم. 


\begin{tabular}{|c|c|c|c|}
\hline \multicolumn{4}{|c|}{ جدول رقم (Y) يوضح نتائج اختبار Mann-Whitney } \\
\hline \multirow{2}{*}{ 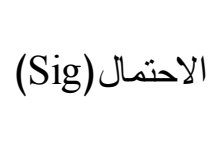 } & \multirow{2}{*}{ إحصائي الاختبار } & \multicolumn{2}{|c|}{ 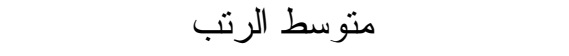 } \\
\hline & & المجمو عة الضابطة & المجمو عة التجريبية \\
\hline 0.038 & 8.624 & 162.89 & 196.34 \\
\hline
\end{tabular}

م التعليق علمى النتائجح :

يتضح من نتائج التحليل الإحصائي لاختبار Mann-Whitney Test أن قيمة P.value نساوي 0.038 (أي 3.8\%) و هي القل من مسستوي المعنويــة

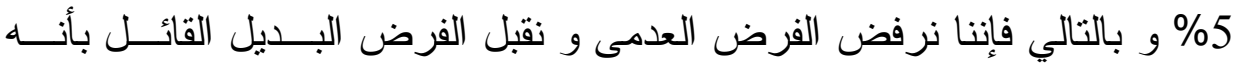
توجد فروق ذات دلالة إحصائية بين منوسطات درجات نظرة أطفال الروضـــة علاقته بالآخرين في المجمو عتين التجريبية و الضابطة بعد تتمية تقـدير الــــات لديهم. r r T الاختبار الإحصائي للفرض الثالث الفرض العدمي (H0) : لا توجد فروق ذات دلالة إحصائية بين متوسطات درجات سلوك أطفال الروضة مع الآخرين في المجموعتين التجرييية و الضابطة بعد تتمية تقدير الذات لليهم.

الفرض البديل (H1) : نوجد فروق ذات دلالة إحصائية بين منوسطات درجات سلوك أطفال الروضة مع الآخرين في المجموعتين التجريبية و الضابطة بعد تتمية تقدير الذات لديهم. 


\begin{tabular}{|c|c|c|c|}
\hline \multicolumn{4}{|c|}{ جدول رقم (r) يوضح نتائج اختبار Mann-Whitney } \\
\hline \multirow{2}{*}{ 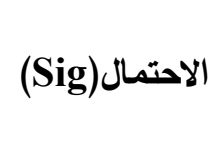 } & \multirow{2}{*}{ إحصائي الاختبار } & \multicolumn{2}{|c|}{ 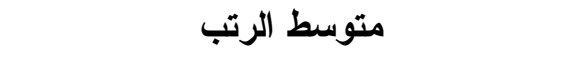 } \\
\hline & & المجموعة الضابطة & المجموعة التجريبية \\
\hline 0.028 & 0.092 & 177.28 & 186.24 \\
\hline
\end{tabular}

م التعليق علمـ النتائجه:

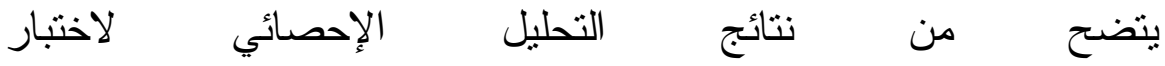
Kruskal Wallis Test هي اقل من مستوي المعنوية 5\% و بالتالي فإننا نرفض الفرض العدمى و نقبل الفرض البديل القائل بأنه نوجد فروق ذات دلالة إحصائية بين منوسطات درجات سلوك أطفال الروضة مع الآخرين في المجموعتين التجريبية و الضابطة بعد تتمية تقدير الذات لديهم.

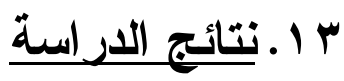

أوضحت الدر اسة وجود علاقة بين بناء وتتمية تقدير الذات لــدى طفـلـل الروضة و تقاعلاته الاجتماعية من خلال النتائج الفرعية التالية : - توجد فروق ذات دلالة إحصائية بين متوسطات درجات نظرة أطفال الروضة لأنفسهم في المجموعتين التجريبية والضابطة بعد تتمية تقدير الذات لديهم - توجد فروق ذات دلالة إحصائية بين متوسطات درجات نظرة أطفال الروضة علاقته بالآخرين في المجموعتين التجريبية و الضابطة بعد نتمية

$$
\text { تقدير الذات لديهم }
$$


- توجد فروق ذات دلالة إحصائية بين متوسطات درجات سلوك أطفال الروضة مع الآخرين في المجموعتين التجرييية والضابطة بعد نتمية

$$
\text { تقدير الذات لديهم }
$$

\section{ع ا ـتوصيات الار اسة}

- - ضرورة مشاركة إدارة الروضات في تحديد الاحتياجات التنريبية للأطفال

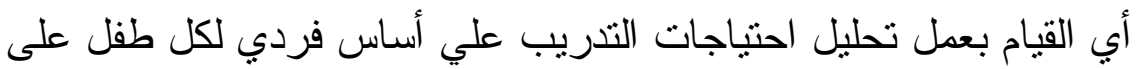
حدى، من جهة آخري هناك ضرورة للتمبيز بين الفئات المختلفة للأطفال بسبب اختلاف المر احل العمرية و الخلفيات الثقافية و الاجتماعية لكل فئة

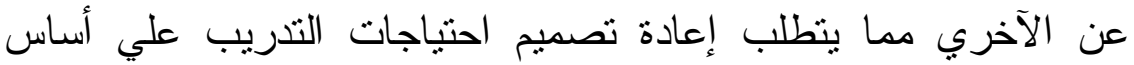
تقسيم الأطفال إلى مجمو عات.

- ضرورة مراعاة مجموعة من الاعتبارات عند تصميم برامج تدريية موجهة للأطفال بحيث تحتوي علي الأثكال و الرسوم و المؤثرات الصوتية التي تساعد علي جذب انتباه الأطفال لفترة زمنية طويلة، إمكانية تحميل المادة العلمية علي الوسائط الالكترونية بحيث يتمكن الأطفال من الناليال

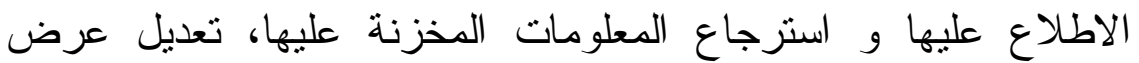
البرنامج بحيث يكون هناك إمكانية تفاعل الأطفال معها. - توسيع استخدام أسلوب التتريب باستخدام الكمبيوتر بحيث يحتوي علي التفاعل بين الأطفال و جهاز الكمبيوتر من خلال وجود خاصية التغذية

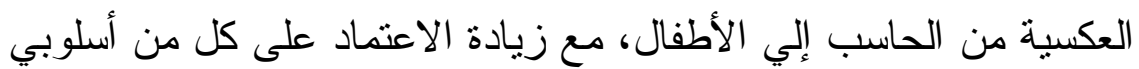

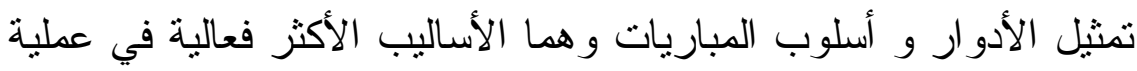


التعلم من خلال ظهور فروق معنوية بين تعلم الأطفال اللذين طبقت

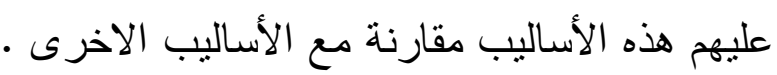
- مشاركة أولياء الأمور في تطبيق البرامج التدرييية و المساعدة في قياس

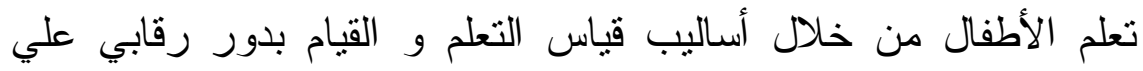

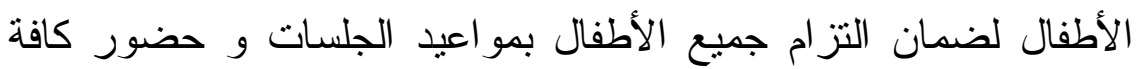

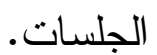

- عدم توحيد أساليب قياس التعلم علي مستوي جلسات البرنامج التدريبي ككل بحيث ينت وضع الأساليب المناسبة لقياس التعلم بكل جلسة تدريبية

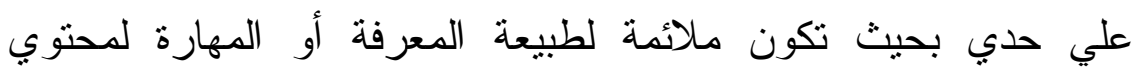
الجلسة، مع عمل نماذج للاختبارات و وضعها علي الموقع الالكتروني لاتئي

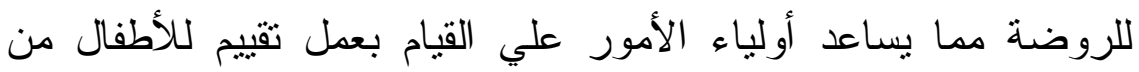

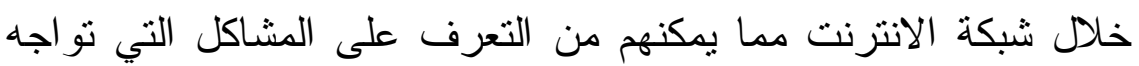

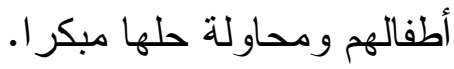




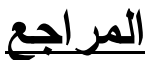

1. أمزيان زبيدة (2007): علاقة تقدير الذات للمراهق بمشكلاته و حاجاته

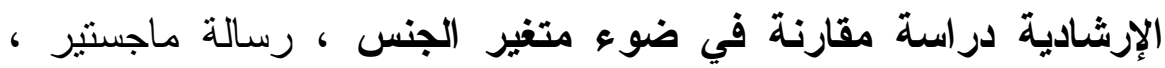
الإرشاد النفسي الددرسي ، كلية الآداب و العلوم الإنسانية، جامعة الحاج

لخضر باتتة

r. انتصار منصور (2012): فاعلية إستراتيجية جداول النثاط المصورة

للتدريب على بعض المهارات الحياتية في تحسين تقدير الذات لاتي الداتي الأطفال المعاقين عقليا القابلين للتعلم، رسالة ماجستير ، الصحة النفسية،

$$
\text { كلية التربية، جامعة حلوان }
$$

r. إيمان عصدت محمود محمد (2016) فاعلية تصميم نموذجين لتريس الرياضيات فى ضوء نظريتى "التلمذة المعرفية" و "البرمجة اللغوية العصبية NLP” ونموذج توليفى منهما فى تنمية التفكير الجاتبي

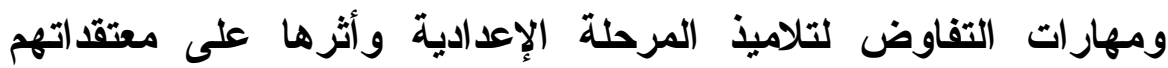

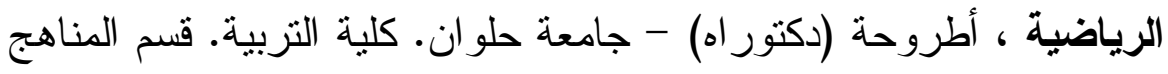
وطرق التدريس.

ع. إيمان محارب (2015): الصلابة النفسية وعلاقتها بتقدير الذات:

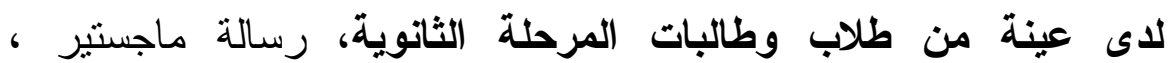
الدراسات النفسية و الاجتماعية ، معهد الدراسات العليا للطفولة، جامعة عين شمس. 
0. إيناس البلتاجي (2014): برنامج كمبيوتر لتنمية مهارة حل المشكلات و

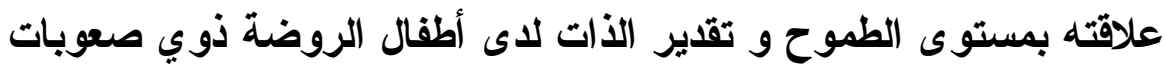

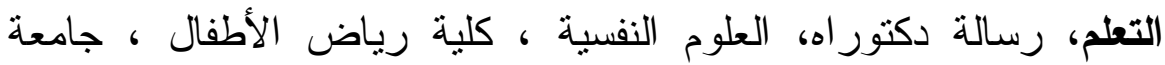

7. رجاء أبو شمالة (2016): جودة الحياة وعلاقتها بتقدير الذات والمهارات

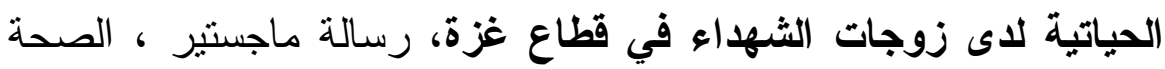
النفسية المجتمعية ، كلية التربية، الجامعة الإسلامية.

V. سعاد أبو بكر موسى الجوهري (2017) المهارات الاجتماعية وعلاقتها بأساليب مواجهة الضغوط النفسية وفعالية الذات لاى عينة من طلاب الداب

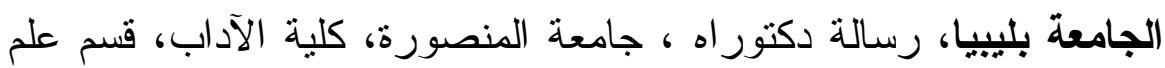
النفس.

^. سلمى عادل عبده سالم (2017) صورة الذات وصورة الأسرة لاى الأطفال المكتببين، رسالة ماجستير، جامعة عين شمس، كلية الآداب، قسم علم النفس.

9. سلوى على (2011): فاعلية برنامج معرفي سلوكي في رفع درجة تقدير

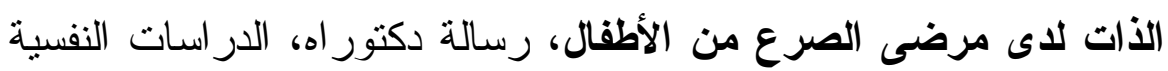
و الاجتماعية ، معهد الدر اسات العليا للطفولة، جامعة عين شمس. •l. صالحة عبيد راثد العجمي (2017) أساليب مواجهة ضغوط الحياة وعلاقتها بكل من تقدير الذات، والجمود لاى العاملين في وزارة الداخلية

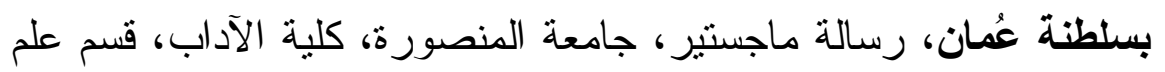
النفس.

المجلد الخامس


11. ضيف العطوي (2006): أثثر نمط التنشئة الأسرية في تقدير الذات لاى

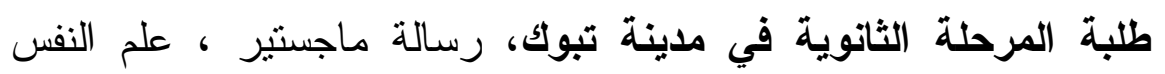
التزبوي ، كلية النربية ، جامعة مؤنة. r ا . عصام ثابت (2010): فاعلية برنامج لتنمية تقدير الذات لاى عينة من

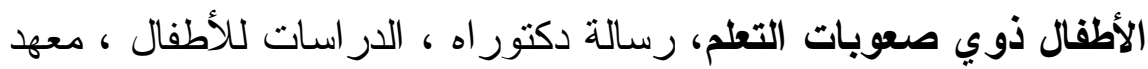

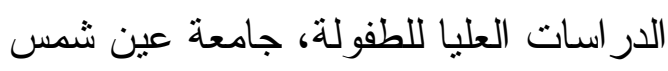

با ا. لمياء رفراف (2015): مستوى تقدير الأت لاى التلاميذ المشاغبين :

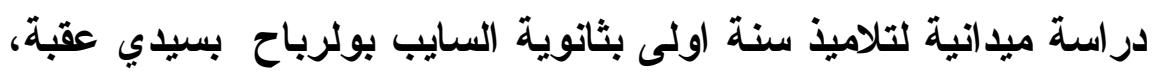

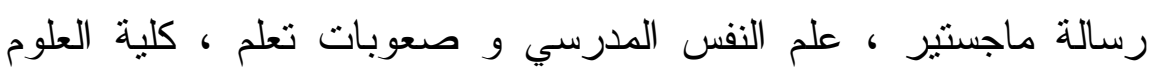

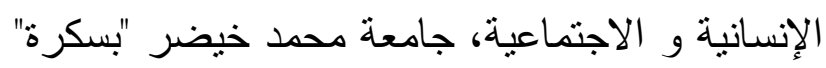

ع ا ـ مايكل فورتين (2009 ): إدارة الحياة ، ترجمة محمد شاهين ، الجيزة ،

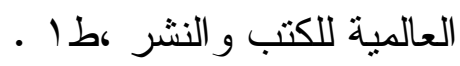
10 ـ محد عاطف غيث (2006)"قاموس علم الاجتماع "،الازاريطة ،دار

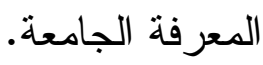

17. نبيل دخان (2011): الذات المهنية للمرشدين النفسيين في العمل الإرشادي التربوي بقطاع غزة، رسالة ماجستير ، علم النفس ، كلية التربية، الجامعة الإسلامية

VV ا. هالة عبد الرحيم يوسف جاد (2017) الأكاء الوجداني وعلاقته بتقدير الأت وجودة الحياة لاي عينة من طلاب الجامعة ، رسالة دكتوراه ،

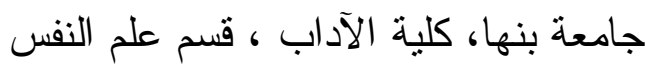


18. Forrester RL, Slater H, Jomar K, Mitzman S, Taylor PJ.(2017) "Self-esteem and non-suicidal self-injury in adulthood A systematic review" Journal of Affective Disorders 221-117 Page 183

19. Nanu Elena Doinita( 2015 ) “Adult Attachment, Selfesteem and Emotional Intelligence" Procedia - Social and Behavioral Sciences 570-574.

20. Onen,A., Mustafaoğlu, F (2015) "The Relationship between Pre-Service Teachers' Self-Esteem and Emotional Intelligence Levels" 5th World Conference on Learning, Teaching and Educational Leadership, WCLTA, Procedia - Social and Behavioral Sciences, Volume 186, Pages1163-1168

21. Seto Mulyadi, Wahyu Rahardjo, A.M. Heru Basuki, $(r+17)$ "The Role of Parent-Child Relationship, SelfEsteem, Academic Self-Efficacy to Academic Stress" Future Academy®'s Multidisciplinary Conference, Procedia - Social and Behavioral Sciences, Volume 217 Pages $603-608$.

22. Stone,J., Cooper, J. (2000) "a self standards model of cognitive dissonance ", Journal of Experimental Social Psychology, Pages 1-15

23. Tafarodi ,R., Swann, W. B. (2001) "two dimensional self esteem: theory and measurement", Personality and individual differences, Volume 31 Pages 653-673. 